\title{
A transition toward a sustainable energy future: feasibility assessment and development strategies of wind power in Taiwan
}

\author{
Cheng-Dar Yue ${ }^{\mathrm{a}, *}$, Chung-Ming Liu ${ }^{\mathrm{a}}$, Eric M.L. Liou ${ }^{\mathrm{b}}$ \\ ${ }^{a}$ Global Change Research Center, National Taiwan University, No. 1, Sec. 4, Roosevelt Road, Taipei 10764, Taiwan, ROC \\ ${ }^{\mathrm{b}}$ Environmental Quality Protection Foundation, 9F-3, No. 100, Sec. 2, Hoping E. Road, Taipei 106, Taiwan, ROC
}

Received 28 December 2000

\begin{abstract}
While the international community has yet to achieve a consensus on the operational details of implementing the Kyoto Protocol, the rapidly increasing consumption of fossil fuels and the $\mathrm{CO}_{2}$ emissions produced in the industrializing developing countries further obscure the prospects for combating global warming. This study analyzes the problems of energy utilization in Taiwan as an illustrative example, and explores the strategies for increasing the market penetration of wind power in the traditional energy structure dominated by fossil fuels and nuclear energy. Decentrally produced wind power would contribute to establishing an autonomous and disaster-resilient power supply system. Replacing partial coal-based power generation with the full exploitation of wind energy would result in annual reductions of 9.8 million tons of $\mathrm{CO}_{2}$ in Taiwan. The key barrier to utilizing wind energy lies mainly in the lack of political impetus and a framework for promoting renewable energy in Taiwan. Priority tasks to allow wind power to penetrate the energy market include establishing legislative prioritization for renewable energy, setting premium prices for power from wind turbines, providing direct support of investment costs, raising awareness, etc. (C) 2001 Elsevier Science Ltd. All rights reserved.
\end{abstract}

Keywords: Sustainable development; Energy policy; Wind energy

\section{Introduction}

Scientists and policy-makers worldwide are increasingly recognizing that global development must be based on a balanced consideration of social, environmental, and economic issues. The prospect of global climate stability which will have a profound influence on global future development relates deeply to whether a transition can occur in the immediate future towards sustainable energy use patterns both at the local and global levels.

For a rapidly industrializing island society like Taiwan, sustainable energy utilization faces a number of challenges at the start of the 21st century. First, in part decision-makers intend to ensure future energy supply through intensifying nuclear power generation which would exacerbate the problems of nuclear waste disposal, and increase the risks of nuclear accidents. Although the

\footnotetext{
* Corresponding author. Tel.: + 886-2-2363-1707; fax: + 886-22363-9154.

E-mail address: dar@gcc.ntu.edu.tw (C.-D. Yue).
}

newly elected government has taken steps to halt construction of the fourth nuclear power plant, the issue is still unresolved. Second, the centralized power supply structure reduces the independence and flexibility of regional power supplies during natural disasters in Taiwan, an area regularly subject to such natural phenomena as earthquakes and typhoons. Third, energy supply principally depends on imported fossil fuels and uranium which together accounted for $96.2 \%$ of total energy supply in 1997. Fluctuations in international energy prices and availability of imported energy supplies could deeply affect domestic socio-economic stability. Finally, the expanding use of fossil fuels due to economic development has resulted in rapidly increasing $\mathrm{CO}_{2}$ emissions. Facing future requirements for reducing $\mathrm{CO}_{2}$ emissions, the government has begun to react to this challenge, including planning the utilization of renewable energy sources. However, only limited results of applying renewable energy technologies have been realized to date.

Renewable energies are regarded as a key factor in mitigating global climate change in the future. Among various renewable energy sources, wind energy in 
particular has achieved maturity in the energy market, and has experienced the greatest growth worldwide over the past few years, as illustrated in Fig. 1. According to the assessment of the Intergovernmental Panel on Climate Change concerning wind energy potential, intermittent wind power on a large grid can contribute an estimated $15-20 \%$ of annual electricity production without special arrangements for storage, backup, or load management (IPCC, 1996). Technical maturity of wind energy has allowed a number of countries to actively exploit this environmentally friendly energy source. However, there have been no effective strategies addressed to promote wind energy as yet in Taiwan.

This study aims to assess the sustainability of current energy utilization in Taiwan, to analyze the feasibility and possible benefits of wind power, and to propose strategies for the market penetration of wind energy in Taiwan. The methodology used in this study explores the following issues:

- definition of sustainable energy utilization;

- sustainability of current and predicted energy utilization in Taiwan;

- feasibility of wind energy development in Taiwan;

- economic, ecological, and social benefits of wind energy in Taiwan; and

- strategies to increase market penetration of wind power in Taiwan.

Hopefully the experience in Taiwan will provide a meaningful example to other developing countries on their path towards sustainable energy utilization.

\section{Definition of sustainable energy utilization}

There has been much discussion concerning the concepts of sustainable development. It is, however, necessary to clearly define the sustainability of energy utilization within the discussion of a transition toward a sustainable energy future in this study. The most widely quoted definition and effectively the official one is that of the Brundtland Report: Sustainable development is development that meets the needs of the present without compromising the ability of future generations to meet their own needs (WECD, 1987). The definition of "needs" differentiates among individual values. The Brundtland Commission's concept particularly emphasizes the essential needs of the world's poor. Generally, the essential needs for the general public can be regarded as the availability and health of the human life support system including air, water supply, land, ecosystems, etc.

Pearce has defined sustainability as making sure that substitute resources are made available as non-renewable resources become physically scarce, and ensuring that the environmental impacts of using those resources are kept

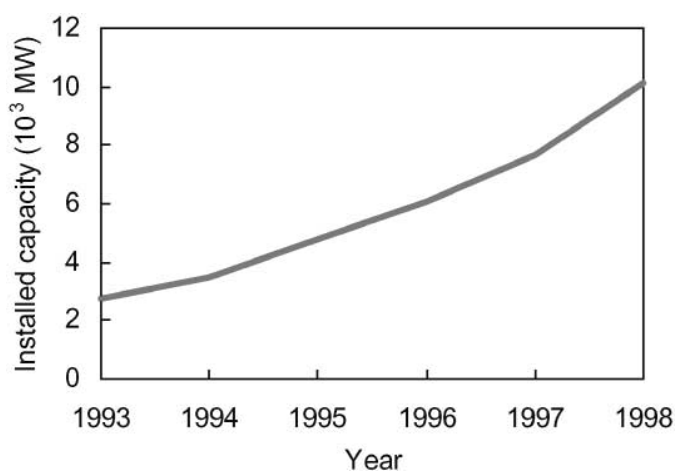

Fig. 1. Worldwide development of wind power (Source: Data extracted from European Wind Energy Association, 2000).

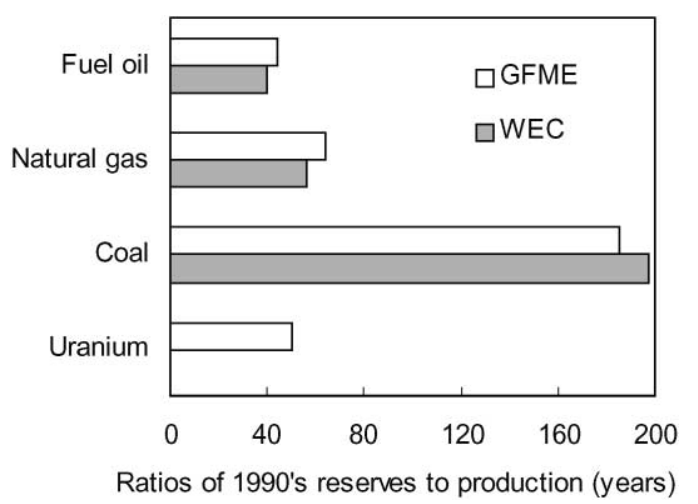

Fig. 2. Availability of worldwide fuel reserves in years as estimated by the World Energy Council (WEC) and German Federal Ministry for Economy (GFME) (Sources: Loske, 1996; GWEA, 1998).

within the Earth's carrying capacity to assimilate those impacts (Pearce, 1993). This concept stresses aspects of both resource availability and environmental safety of the long-term security of resource utilization.

Sustainable energy utilization should take into consideration satisfying essential human needs for both this and future generations. In terms of resource utilization, the sustainability of energy utilization implies that the satisfaction of present energy utilization should consider the energy requirements of the future. Fuel oil, natural gas, and uranium will possibly only be available until the middle of the 21st century considering global energy consumption trends and technical conditions of future energy exploitation, as Fig. 2 illustrates. In this context, sustainable energy utilization means sparing non-renewable energy sources, and replacing non-renewable energy sources with renewable sources. In view of ecological impacts, the sustainability of energy utilization implies that the ecological impacts of energy exploitation and utilization should be kept within the carrying capacity of natural systems for assimilating those impacts in order to ensure the health of the human life support system such as air, water, land, and ecosystems. 
In the Brundtland Report, sustainable development deals with social issues such as inter- and intragenerational equity. While increased political attention has been focused on economic development and environmental protection over the last decades, the issue of satisfying the needs of economically and environmentally weak groups in society was brought to the political arena after the Brundtland Report. The environment, growth, and equity are regarded as the main components of sustainability (Kirkby et al., 1995). At the heart of the Brundtland Report is the belief that equity, growth, and environmental maintenance are simultaneously possible with each nation achieving its full economic potential while at the same time enhancing its resource base. The institutional dimension plays a particularly significant role in Agenda 21 in order to respond to all these economic, ecological, and social challenges (UNCSD, 2000). These dimensions constitute the main basis of the following discussions in this study.

\section{Sustainability of energy utilization in Taiwan}

Energy consumption has increased rapidly in Taiwan since the 1970s. The nation's energy supply has increased 2.6 times from 1977 to 1997, as Fig. 3 illustrates, mainly due to industrialization and economic growth. With regard to another critical issue of energy structure, energy supply in Taiwan relies mainly on fossil fuels and nuclear energy which had respective shares of $87.1 \%$ and $11.7 \%$ of total energy supply by 1997. Imported fossil fuels and nuclear energy comprised $96.2 \%$ of total energy supply in 1997 (ECROC, 1998). Oil plays the most important role among the various energy sources. After the oil crisis of the 1970s, nuclear energy began to penetrate our energy supply. Renewable energy sources, with the exception of hydropower, had not yet been integrated into the energy market by 1997 . The delay in introducing renewable energy is mainly attributed to the shortcomings of institutional capabilities for a transition in energy policy. The predominant arguments in Taiwan's energy policy are that the output of renewable energy sources is limited, and that it would not be able to provide sufficient energy supplies for total energy consumption on one hand, while the costs of renewable energy sources are too high to compete with fossil fuels and nuclear energy on the other. The issues of the technical potential and the costs of wind energy in Taiwan will be further discussed in the next section of this study.

It appears that the current trends of energy utilization in Taiwan will extend into the first decades of the 21st century. Primary energy consumption in Taiwan is set to increase by $90 \%$ from 1997 to 2020 according to the government's predictions, as illustrated in Fig. 4. Fossil fuel and nuclear will have respective shares of $85.8 \%$ and $11.4 \%$ by 2020 , while hydro and new renewable energy

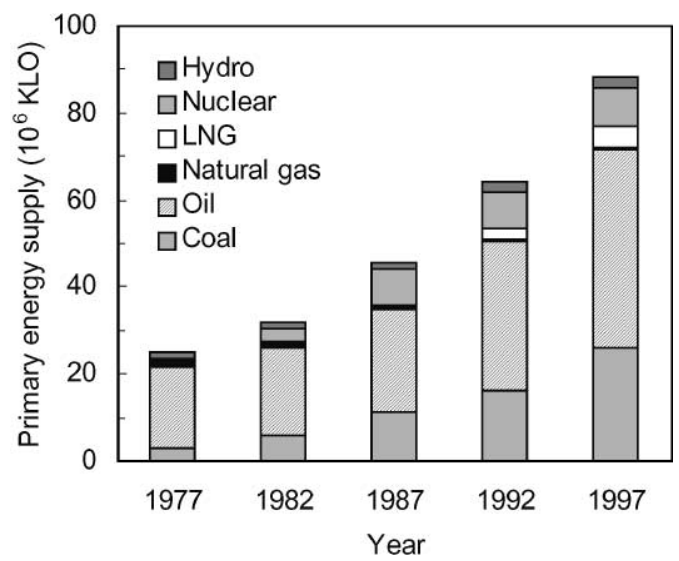

Fig. 3. Primary energy supply in Taiwan (Source: Data extracted from ECROC, 1998).

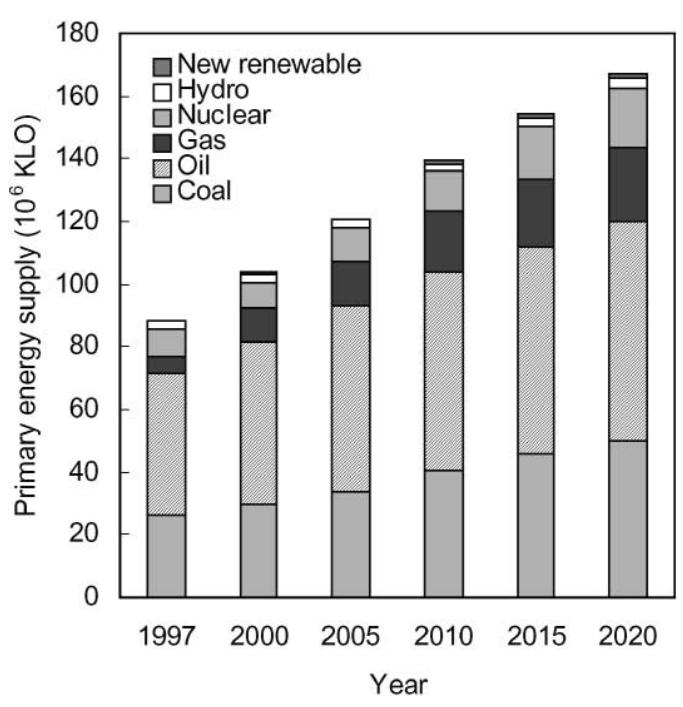

Fig. 4. Predicted primary energy supplies in Taiwan (Source: Data extracted from ECROC, 1998).

sources will respectively account for only $1.7 \%$ and $1.1 \%$. Changes in the energy structure are not obvious during this period with the exception of an increased share of natural gas.

The expanding utilization of fossil fuels due to industrialization and economic development has brought about rapidly increasing $\mathrm{CO}_{2}$ emissions since the 1970s, as shown in Fig. 5. The national energy-related $\mathrm{CO}_{2}$ emissions in Taiwan by 1997 at $189.41 \times 10^{6}$ tons were less than those of Spain at $253.82 \times 10^{6}$ tons and more than those of the Netherlands at $184.31 \times 10^{6}$ tons (see Fig. 6). The energy-related per-capita $\mathrm{CO}_{2}$ emissions in Taiwan by 1997 at 8.74 tons were lower than those in Korea at 9.18 tons, and higher than those in Greece at 7.69 tons (see Fig. 7). The high rate of growth in $\mathrm{CO}_{2}$ emissions in Taiwan can be attributed to population and 


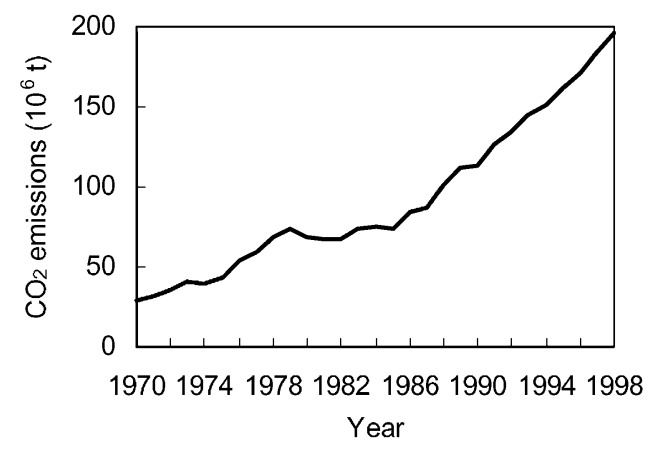

Fig. 5. $\mathrm{CO}_{2}$ emissions caused by fossil fuel combustion in Taiwan (Source: Data extracted from EPA, 1999).

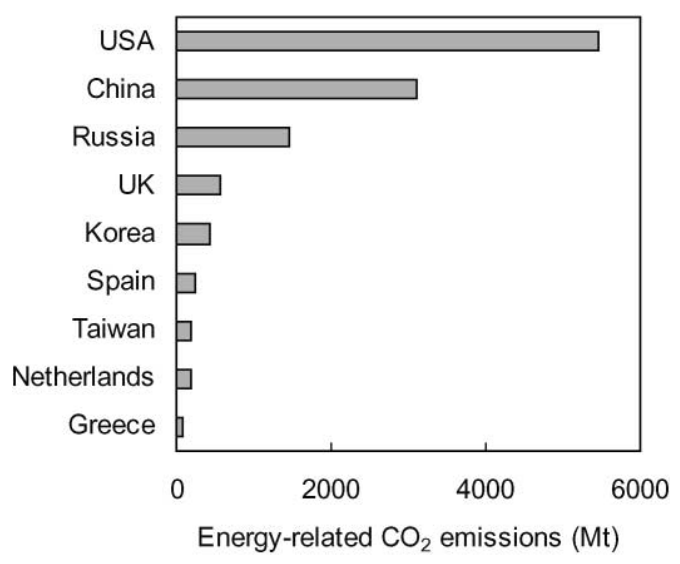

Fig. 6. Energy-related $\mathrm{CO}_{2}$ emissions by 1997 (Source: IEA, 1999).

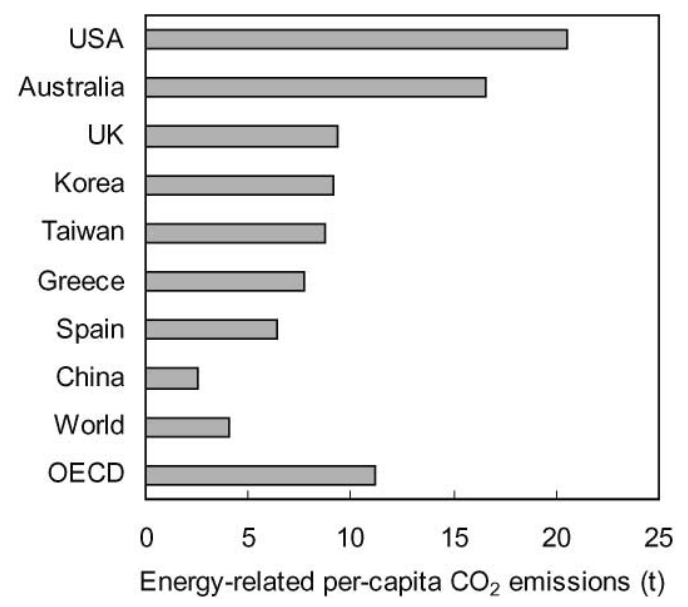

Fig. 7. Energy-related per-capita $\mathrm{CO}_{2}$ emissions by 1997 (Source: IEA, 1999).

economic growth, and very rapid increases in the output of the heavy industries required to construct the facilities and infrastructure for modernizing the economy. This is consistent with the analyses made by Weyant and Yanigisawa (1998).
Intensifying the utilization of nuclear energy is another controversial issue currently under debate in Taiwan. The building of a new plant has engendered enormous opposition from both governmental and civilian organizations and communities. Advocates of nuclear energy argue that its utilization will stabilize economic development and mitigate $\mathrm{CO}_{2}$ emissions. The newly elected government announced a halt to the construction of the fourth nuclear power plant in an effort toward a transformation to sustainable energy use in Taiwan. The opposition parties argue that the decision of the new government was arbitrary and that it does not take into account the opinions of the dominant opposition parties in the legislature who favor continuing the construction of the plant. As a result, the opposition parties have established an alliance and have announced their intention to recall the President through legal procedures. In order to determine whether halting the construction of the fourth nuclear power plant violates the constitution, the new government is applying for a review by the Grand Justices. Observing this event to date, two points are of crucial importance. First, the long-term energy policy and its rationale should be clarified. The rationale of the new government's proposed alternative to replace the fourth nuclear power plant with gas-based power plants should be made sufficiently convincing to the opposition parties and the general public. Second, discussions of the nuclear power plant have changed from a technical to a political and social issue. The government's decision-making process should accommodate procedures for consultation and discussion with the opposition parties, and for raising the awareness of the general public.

The controversy surrounding nuclear energy results from its incalculable risks and the thorny problem of waste disposal. This consideration can be recognized by the EU's resolution specifically ruling out increased use of nuclear power as an option to mitigate $\mathrm{CO}_{2}$ emissions (ECDGE, 1998). The sites for depositing nuclear wastes are planned at existing nuclear power plants after treatment. Negotiations with the governments of North Korea, Russia, and China are underway for ultimate deposit sites in foreign countries as opposed to looking for domestic ultimate deposit sites on remote islands (Lee, 2000). Partially treated nuclear wastes are currently deposited on Lanyu (Orchid Island) off the southeast coast of Taiwan. For this reason, the aboriginal inhabitants of this island have been judged to be "environmental refugees" by the United Nations. In the past, contamination of more than 1600 households, eight roads, 15 schools, and a water plant by radioactive accidents has been recorded in Taiwan (Chang et al., 1997; Wang, 2000). Mutations in fish and the bleaching of coral reefs were observed in coastal areas near nuclear power plants. The deposition of nuclear wastes in Taiwan which is subject to frequent earthquake activities, the transportation of 
radioactive wastes, and the potential nuclear reactor accidents produce incalculable risks for this area.

In conclusion, the increasing consumption in Taiwan of non-renewable energy sources such as fossil fuels and nuclear energy may lead to their exhaustion from the point of view of resource utilization. With regard to ecological impacts, the reliance on fossil fuels and nuclear energy increases the risks of global warming and radioactive accidents, respectively. All these suggest that the current and predicted energy use patterns in Taiwan are not consistent with sustainability.

\section{Conditions for wind energy in Taiwan}

\subsection{Technical potential}

By determining the total land area that has annual mean wind speeds appropriate for wind energy, a study by the Energy Commission of the Republic of China (ECROC) has estimated that land areas with mean wind speeds greater than 5 and $4 \mathrm{~m} / \mathrm{s}$ reach 2070 and $8046 \mathrm{~km}^{2}$, respectively, as illustrated in Fig. 8. According to Kaltschmitt and Wiese, areas with annual mean wind speeds of more than $4 \mathrm{~m} / \mathrm{s}$ already possess the technical potential of exploiting wind energy (Kaltschmitt and Wiese, 1994). van Wijk and Coelingh assumed that only $4 \%$ of land which had a mean wind speed greater than $5.1 \mathrm{~m} / \mathrm{s}$ could be used as a result of practical and social constraints (van Wijk and Coelingh, 1993). ECROC assumed that only $2.5 \%$ of land with wind speed of more than $5 \mathrm{~m} / \mathrm{s}$ could practically be used to install wind turbines in Taiwan considering land acquisition problems. Accordingly, an area of about $50 \mathrm{~km}^{2}$ could be used to install wind turbines (ECROC, 1999). Using wind turbines with a rated capacity of $1.8 \mathrm{MW}$, about 926 wind turbines of 60-m diameter could be installed. Thus the technical potential of onshore wind power is calculated to be $1667 \mathrm{MW} /$ year in Taiwan.

In terms of offshore wind potential, ECROC has estimated the area with excellent wind potential and water depths of between 5 and $15 \mathrm{~m}$ to be $700 \mathrm{~km}^{2}$. Only $10 \%$ of that area could be used to install wind turbines as a result of practical constraints. Therefore, $70 \mathrm{~km}^{2}$ could be used to install wind turbines (ECROC, 1999). About 1296 wind turbines of a rated capacity of $1.8 \mathrm{MW}$ could be installed in these areas. Thus the technical potential of offshore wind power is calculated to be $2333 \mathrm{MW} /$ year in Taiwan. In total, the technical wind potential of onshore and offshore areas is calculated at $4000 \mathrm{MW}$ in Taiwan. With a capacity factor of 0.25 , these turbines would be capable of generating approximately $10 \mathrm{TWh}$ annually, which is equivalent to $6.5 \%$ of Taiwan's electricity demand in 1999. According to the government's predictions, coal-based power plants will generate $131 \mathrm{TWh}$ of electricity accounting for $41 \%$ of total generated

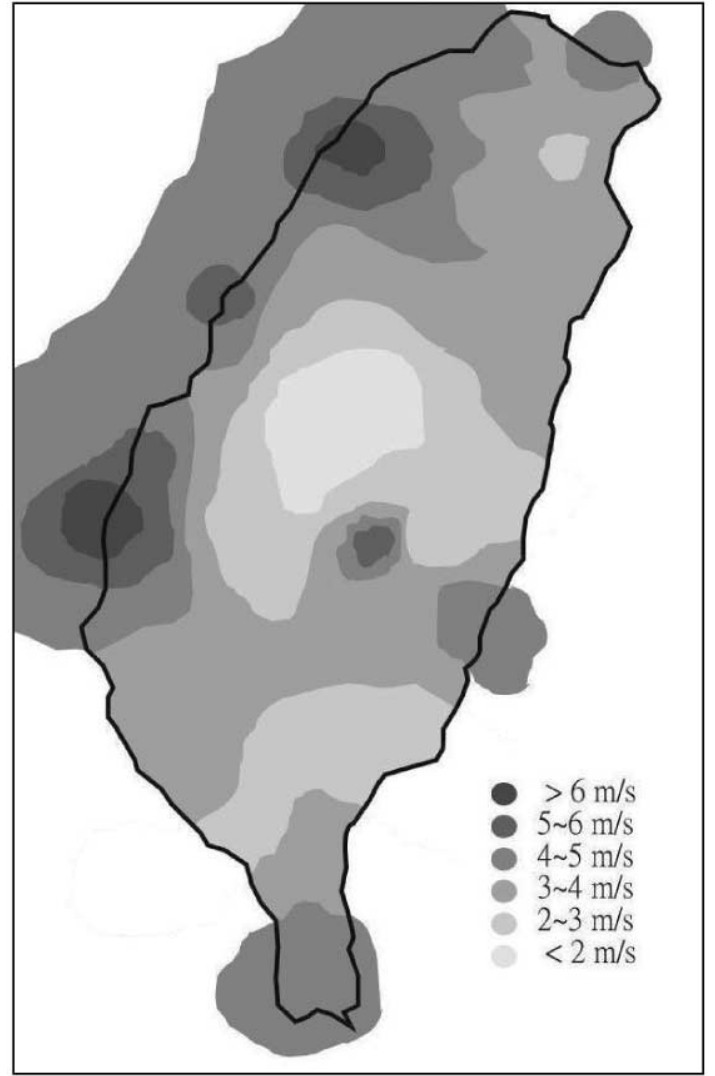

Fig. 8. Wind potential distribution in Taiwan (Source: ECROC, 1999).

electricity by 2020 (ECROC, 1998). Partially replacement of coal-based power generation by full exploitation of wind energy would be capable of covering about $3.3 \%$ of the entire electricity demand of $305.7 \mathrm{TWh}$ by 2020 in Taiwan.

The estimate above adopts the approach of exploiting the wind potential of wind speeds greater than $5 \mathrm{~m} / \mathrm{s}$. Further improvements in the technology will extend the potential for utilizing winds at speeds of less than $5 \mathrm{~m} / \mathrm{s}$, which would lead to a significant increase in the wind share.

\subsection{Costs}

The cost of wind energy is determined by factors such as energy production, capital costs, etc. The cost per unit of electricity generated by a wind farm can be estimated using the following formula (with the values in brackets based on the year 1999 in Taiwan) (ECROC, 2000):

$$
C w=\frac{C o(C R F+M)}{E},
$$

where $C w$ is the cost per unit of electricity generated by the wind farm; $C o$ the capital cost of the wind farm (1094 
US\$ $/ \mathrm{kW}$ ); and $C R F$ the annual capital charge rate:

$$
C R F=\frac{\operatorname{Ir}(1+I r)^{n}}{(1+I r)^{n}-1}
$$

where $I r$ is the required annual rate of return net of inflation $(6 \%) ; n$ the number of years over which the investment in the wind farm is to be recovered (20); $M$ the rate of annual cost of operating and maintaining the wind farm (3\%); and $E$ is the wind farm annual energy output $(2500 \mathrm{~kW} \mathrm{~h} / \mathrm{kW})$.

With this approach, the cost of wind power generation is calculated to be 5.1 US cents $/ \mathrm{kW}$ h by 1999 in Taiwan. This cost is slightly higher that of fossil fuel oil at 4.8 US cents $/ \mathrm{kWh}$, and is lower than that of natural gas at 6.8 US cents/kW h by 1999 in Taiwan, as depicted in Fig. 9. Actually, wind power of state-of-the-art wind turbines is 4.7 US cents $/ \mathrm{kW}$ h by 1998 . The results of several studies indicate that the cost of wind power is expected to decrease continuously in the future through technological advancement and cost depression caused by mass production. A study by the US Department of Energy in 1993 predicted the cost would be 3.6 US cents $/ \mathrm{kWh}$ in 2010. Similar results were produced by a Danish study at 4 US cents/kW h by 2005 and 3.2 US cents/kW h by 2020 .

Cost calculations by Taiwan Power Company for nuclear power generation are being challenged by some economic and energy experts. In addition, the costs induced by losses from throttling down other power plants in order to match the operation of the nuclear power plants, and those from using nuclear power to operate pumped storage installations, etc. have not been included in the cost calculations for nuclear power generation. The loss of about $35 \%$ which occurs in the Ming-Tan pumped storage power plant located in central Taiwan is an example of this case.

Moreover, a direct comparison between wind energy prices and those of a thermal plant is misleading, as wind energy has lower external costs and often has higher value. Generally, electricity prices do not include the external costs of electricity generation that are associated with damage to health and the environment. External costs of power plants need to be taken into account when comparing wind energy prices particularly with fossil fuels and nuclear power plants due to their high external costs. Wind energy must also be credited with additional value, as it is usually injected into low-voltage distribution networks, enabling utilities to save on transmission costs. When the external costs of other fuel sources and system benefits of wind are taken into account, wind's competitive position is strengthened.

\subsection{Current development of wind energy}

Since 1979 after the second international oil crisis, the government in Taiwan has commissioned research on

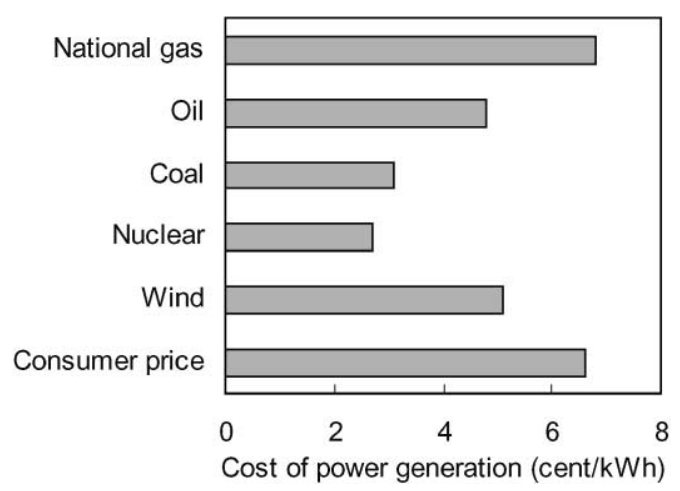

Fig. 9. Cost of power generation by 1999 in Taiwan with various energy sources in comparison to consumer price (Source: Taiwan Power Company, 1999).

wind energy applications under the consideration of diversifying energy sources. Research and development of wind turbines with capacities of 4,40 , and $150 \mathrm{~kW}$ were conducted in the $1980 \mathrm{~s}$. Two $100 \mathrm{~kW}$ machines were installed on a remote island off the west coast of Taiwan in 1991 for demonstration purposes. The operation of both machines was stopped in 1993 as a result of excessive capacity in comparison with the small local electricity demand, as well as of the problem of turbulence at the site. Although there has been global action against climate warming in the 1990s, the development of wind energy has not gained importance in Taiwan due to the global low level of fossil fuel prices. The newest breakthrough will be achieved with the installation of four $660 \mathrm{~kW}$ machines for private use in an industrial park at the end of the year 2000, and an additional four $600 \mathrm{~kW}$ machines for local electricity supplies on a different remote island off the west coast of Taiwan at the end of 2001.

Low prices for fossil fuels have reduced the motivation of Taiwan's government to actively promote renewable energy. Lacking the political will and a political framework for promoting renewable energy prevents the development of wind energy despite the technical maturity of wind energy on the market. Newly industrialized nations, including Taiwan, and developing countries have not yet been assigned any binding $\mathrm{CO}_{2}$ reduction targets as negotiated by the UNFCCC. The government has estimated that new renewable energy would have a share of only $1.1 \%$ in total primary energy supply by 2020 (ECROC, 1998), indicating a low political willingness to invest in renewable energy for Taiwan's future.

A statistical comparison in Table 1 indicates that per capita electricity consumption in 1997 in Taiwan was generally higher than that of a number of OECD countries. Up to 1999 , wind energy had not yet been integrated into the energy market. Although technically there is wind potential, the high population density appears unfavorable for the installation of wind turbines in 
Table 1

Technical potential for onshore wind power and statistics in selected countries (Sources: IEA, 1999; ECDGE, 1998; New Energy, 2000) ${ }^{\mathrm{a}}$

\begin{tabular}{|c|c|c|c|c|c|c|c|c|c|}
\hline Country & Area $\left(\mathrm{km}^{2}\right)$ & $\begin{array}{l}\text { Population } \\
1997 \\
\text { (million) }\end{array}$ & $\begin{array}{l}\text { Population } \\
\text { density } \\
\text { (people } / \mathrm{km}^{2} \text { ) }\end{array}$ & $\begin{array}{l}\text { Technical } \\
\text { potential } \\
\text { (TWh/year) }\end{array}$ & $\begin{array}{l}\text { Installed } \\
\text { capacity } 1999 \\
(\mathrm{MW})\end{array}$ & $\begin{array}{l}\text { Installed } \\
\text { capacity per } \\
\text { area } \\
\left(\mathrm{kW} / \mathrm{km}^{2}\right)\end{array}$ & $\begin{array}{l}\text { Installed } \\
\text { capacity per } \\
\text { capita } \\
(\mathrm{W} / \text { person })\end{array}$ & $\begin{array}{l}\text { Electricity } \\
\text { cons. } 1997 \\
(\mathrm{TWh})\end{array}$ & $\begin{array}{l}\text { Electricity } \\
\text { cons. per } \\
\text { capita } 1997 \\
\text { (kW h) }\end{array}$ \\
\hline Netherlands & 41,526 & 15.61 & 376 & 7 & 411 & 9.90 & 26.33 & 95.56 & 6122 \\
\hline Ireland & 70,273 & 3.66 & 52 & 44 & 73 & 1.04 & 19.95 & 18.29 & 5002 \\
\hline Portugal & 92,345 & 9.95 & 108 & 15 & 60 & 0.65 & 6.03 & 33.82 & 3401 \\
\hline Greece & 131,957 & 10.49 & 79 & 44 & 82 & 0.62 & 7.82 & 41.98 & 4003 \\
\hline Belgium & 30,528 & 10.18 & 333 & 5 & 9 & 0.29 & 0.88 & 78.43 & 7703 \\
\hline Taiwan & 36,000 & 21.68 & 602 & 4 & 0 & 0.00 & 0.00 & 146.40 & 6752 \\
\hline
\end{tabular}

${ }^{\mathrm{a}}$ Note: cons. $=$ consumption.

Taiwan. Under these circumstances, institutional capability is particularly required for the exploitation of wind energy in Taiwan.

\section{Significance of wind energy for Taiwan}

\subsection{Energy and economic benefits}

Renewable energy is expected to play an important role in constituting a global sustainable energy structure in the 21st century. From the point of view of land required per GWh of electricity produced for 30 years, wind energy requires an area of about $1068 \mathrm{~m}^{2}$ taking into account the total fuel cycle, as illustrated in Fig. 10. Photovoltaic and solar thermal would require an area of 3237 and $3561 \mathrm{~m}^{2}$, respectively, to produce the same amount of electricity. Another study indicates that a wind turbine uses 0.0036 ha to produce between $(1.2$ and 1.8$) \times 10^{6} \mathrm{kWh} /$ year, while a typical biofuel plant would require 154 ha of willow forest to produce $1.3 \times 10^{6} \mathrm{~kW} \mathrm{~h} /$ year. Solar cells would require an area of 1.4 ha to produce the same amount of electricity per year (DWTMA, 2000). From this comparison it can be seen that wind energy could play an extraordinarily significant role for Taiwan, an island with high population density, due to its small land resource requirements.

Climatic fluctuations of wind are often regarded as a barrier to greater contributions of wind energy to power supplies. This appears obvious for the case of a single wind turbine since each wind gust directly influences power output. However, if all installed wind turbines nationwide were integrated as a network, strong fluctuations would be compensated for. The relative width of the fluctuation falls approximately in inverse proportion to the second root of the number of wind turbines, as the formula below depicts (GWEA, 1998):

$$
\Delta P_{\Sigma}=\sum(\Delta P i) / \sqrt{n},
$$

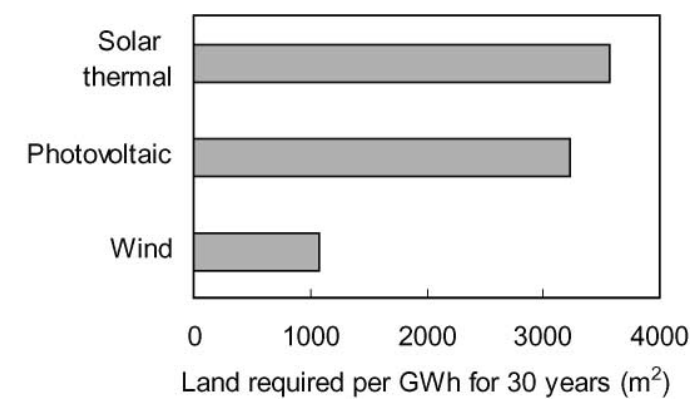

Fig. 10. Land required per GWh for 30 years by generation technology (Source: ECDGE, 1998).

where $\Delta P_{\Sigma}$ is the total fluctuation; $\Delta P i$ the fluctuation of various individual wind turbines; and $n$ the total number of wind turbines.

In cases of an increasing wind power share in the grid, reserve power plants should be available for longer calm times. This task could be fulfilled by existing power plants in the short term, and by power plants of other renewable energies such as biomass and hydraulic energies in the long term. In other words, wind power plants must be supported by other power plants to compensate for longer calm times.

Locally produced wind energy can reduce the dependence on imported fossil fuels and uranium, and would enhance the independence and flexibility of the regional power supply. During natural disasters, utilization of wind energy could reduce the dependence on large-sized power plants and the transmission networks subject to the effects of the natural disasters. This is especially significant for building up a disaster-resilient power supply system in Taiwan, an area subject to such phenomena as earthquakes and typhoons. The case of the Chi-chi earthquake, magnitude (ML) 7.3, on 21 September 1999 in central Taiwan, provides a good example. After this earthquake, electricity transmission from the southern to the northern parts of the island was seriously damaged as a result of the collapse of an extra-high-voltage 
substation in central Taiwan. Consequently, the electricity supply for the northern part of the island was disrupted for several days resulting in great losses particularly in production in the electronics industries in the north. It would therefore be beneficial to increase the power supply capacity in the north by the installation of power plants using renewable energy sources.

Wind energy produces decentralized electricity closer to consumer demand than does centralized generation, and widely avoids the losses that occur in the long energy conversion chain from primary energy to active current. Widely distributed small-scale generation could stabilize the supply in areas remote from generation and defer the need for main transmission reinforcement.

\subsection{Ecological benefits}

Wind energy development has both positive and negative environmental impacts. The ecological benefits of wind energy can be discussed in terms of material utilization and environmental impact. The materials used for wind turbines can be completely and safely recycled. The foundations and towers of wind turbines can be reused after detailed material examination. The gears and generators are made of materials that can be recycled. The rotor blades are made of synthetic material that can be reused as well. Reusing the material of wind turbine conserves the Earth's resources.

In terms of environmental impacts, the generation of electricity by wind turbines does not involve the release of $\mathrm{CO}_{2}$, acid rain, smog, or radioactive pollutants. Furthermore, locally produced wind energy avoids risks of accidents during the transportation of radioactive material and fossil fuel. With respect to the most important greenhouse gas, $\mathrm{CO}_{2}$, wind power produces about $8 \mathrm{~g}$ $\mathrm{CO}_{2} / \mathrm{kW}$ h of electricity which is far less than that of coal, oil, and natural gas, as Fig. 11 illustrates. Power generation on average produced $630 \mathrm{~g} \mathrm{CO}_{2} / \mathrm{kWh}$ in 1998 in Taiwan (Young, 1999). This means that each $\mathrm{kWh}$ of wind power produced could spare an average of about $620 \mathrm{~g}$ of $\mathrm{CO}_{2}$. Note that replacing coal with wind power to produce electricity represents one of the lowest $\mathrm{CO}_{2}$-abatement costs of all options available. When substituting for coal-based power generation, each $\mathrm{kWh}$ produced by wind power can reduce emissions of $\mathrm{CO}_{2}$ by about 980 g. Replacing partial coal-based power generation by the full exploitation of wind energy would result in a reduction of 9.8 million tons of $\mathrm{CO}_{2}$ annually, which corresponds to $5 \%$ of the national $\mathrm{CO}_{2}$ emissions caused by the combustion of fossil fuels in 1998 in Taiwan.

Wind energy development also has certain environmental impacts, including noise, electromagnetic interference, visual impact, and flicker caused by sunlight interacting with rotating blades on sunny days. With technical advancements over the past few years, noise is no longer a problem for modern wind turbines that are

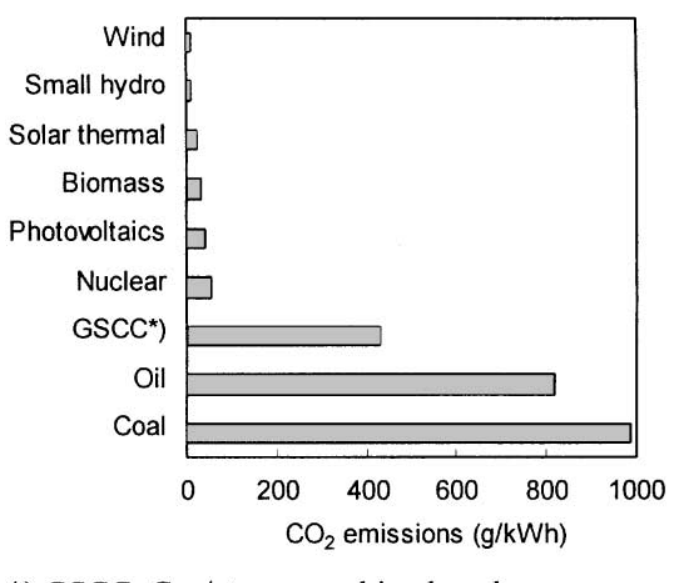

*) GSCC: Gas/steam combined cycle

Fig. 11. $\mathrm{CO}_{2}$ emissions from different electricity generation technologies (Source: ECROC, 1999).

carefully sited. Careful design of a wind farm will avoid disturbances to telecommunications systems. The effect of the periodic reflection or interruption of sunlight has been addressed by careful consideration of machine siting and of the surface finish of the blades. Generally, negative impacts can be kept to the minimum through regulatory, technical, and planning measures. Environmental impact assessments or environmental statements are tools to achieve this aim. As a result, the environmental benefits of wind energy greatly outweigh its ecological costs. Some environmental organizations worldwide have expressed the opinion that wind energy has an ecologically and economically justifiable and significant role in the energy mix of the future (Musiol, 1999). A number of public opinion polls conducted in UK and Germany indicate that wind energy is well accepted and advocated by the general public.

\subsection{Socioeconomic benefits for rural areas}

Wind power is produced almost exclusively in rural areas. On terrestrial land, 99\% of the area around wind turbines would still be available for agriculture, livestock breeding, and biomass planting, as only $1 \%$ would be needed for turbine foundations, assess roads, etc. The planting of biomass can further exploit new energy sources, increase the energy productivity per unit area, and serve as an ideal complement to wind energy during calm periods. All these measures will significantly increase the income of farmers and utilities that install wind turbines on their land, and help retain ecologically significant farmland in Taiwan. For projects in offshore areas, the transformation of economic structure from fisheries to wind energy provides new employment prospects for coastal areas.

Wind energy results in high employment due to its decentralized power generation. By building many small 
power plant units, the work processes of manufacturing, planning, installation, operation, service, maintenance, and operating surveillance of wind power generation are continuously repeated. All these are expected to attract enterprises from the outside to move into rural areas, and they require local workforces. The experience in the Muppandal region in India is living proof of this development. The employment and abundant income generated by wind energy has changed this once extremely poor and underdeveloped area. Valliyoor, a formerly abandoned place at the edge of the wind farm, has become a town with many new buildings, including bank branches, an insurance company, and a market place. Increasing numbers of young Indians are learning the trade of wind power maintenance despite lacking training facilities for wind power jobs. Local inhabitants have set up a great number of small shops that produce income mainly from stocking and making spare parts (Thothathri, 1999). Such employment effects occur in Germany as well. Almost 15,000 jobs have been created, many in the economically weak areas of northern Germany (European Wind Energy Association, 2000).

In contrast to Western countries where regenerative energies are used mainly to ease the strain on the environment, the benefit to states like India or China lies mainly in clean power stations being able to generate employment and prosperity for underdeveloped areas. Wind energy is regarded as an ideal technology not only for developing countries, but also for some economically weak areas in Taiwan. Wind turbines can easily be installed in developing countries, and serviced and maintained locally. Manufacturers will often manufacture heavy parts of the turbines locally once the installation rate reaches a certain level. These examples can be elucidated by the experience in Asia. India has become one of the large wind energy nations of the world with substantial local manufacturing. Mainland China is presently taking the lead in East Asia (DWTMA, 2000).

The feasible combination among wind energy and other economic sectors, such as biomass planting, agriculture, livestock breeding, and fisheries, implies promising prospects for areas traditionally with weak economic structures in Taiwan. Wind energy represents socioeconomic significance for the promotion of local sustainable economic activity. The reinforcement of local business in this way would increase trade tax revenues at the local level, reduce differences in living standards between urban and rural areas, and promote balanced regional development.

\section{Strategic implications}

Due to its low ecological impacts and competitive power generation costs, wind power is being politically promoted by a large number of countries worldwide.
Providing sufficient incentives in the initial stage is strategically significant to the development of wind energy. By examining the successful experiences of countries that have increased the market penetration of wind power in the traditional energy structure dominated by fossil fuels and nuclear energy, some conclusions have been reached regarding significant measures required.

\subsection{Legislative priority for renewable energy}

Article 2(v) of the Kyoto Protocol requires that Annex I Parties phase out market imperfections and subsidies for all greenhouse gas-emitting sectors. Article 3, paragraph 2 states that each Party included in Annex I shall increase the share of renewable energy with demonstrable progress. Due to the ecological imperative of renewable energy for sustainable energy utilization, legislative priority for renewable energy should be set politically. This means that legislative priority should procure for renewable energy the capacity and priority dispatch for producing energy, obligating utilities and grid operators to connect wind turbines to their grids. The costs of grid infrastructure development and reinforcement should be carried by the grid management authority rather than by individual renewable projects. The experience in Costa Rica and Germany indicates that the priority of renewable energy sources in national energy supply drives the transition towards a more sustainable national energy structure (New Energy, 1998; Glaser, 2000).

\subsection{Support through the premium price of power from wind turbines}

Use of premium prices paid per kilowatt-hour has been shown to be the most effective tool for stimulating markets in India, Denmark, Spain, and Germany (ECDGE, 1998; Hinsch, 1999; Thothathri, 1999). A German feed-in law put in force in January 1991 required utilities to pay at least $90 \%$ of the retail consumer price. These subsidies were limited to 10 years. In Taiwan, the current generating cost of wind energy at 5.1 US cents $/ \mathrm{kWh}$ is lower than the consumer price at $6.6 \mathrm{US}$ cents $/ \mathrm{kWh}$. In the initial phase, a higher remuneration price would be meaningful in order to attract investment. A fixed remuneration price of $6.25 \mathrm{US}$ cents $/ \mathrm{kW} \mathrm{h}$ would result in an amortization time of 13 years in Taiwan (ECROC, 2000). Considering the depreciation time of 20 years of a wind turbine, this can produce a great incentive for investment.

\subsection{Direct support of investment costs}

The use of direct grants to cover a proportion of investment costs has proven to be an effective way of supporting development, particularly in the early stages. 
Applying this economic instrument would lighten the load of investment costs. An illustrative example is the government's program in Denmark which offered 30\% of the total investment cost at the initial stage of wind energy development; it lasted for 10 years at a declining rate (ECDGE, 1998). Government could use an energy fund, one already available and intended for promoting climate-friendly energy sources and revenue from an air pollution tax to cover a proportion of installation costs of wind turbines in Taiwan.

\subsection{Liberalization of the electricity market}

The electricity market in Taiwan is currently monopolized by the state-run utility, Taiwan Power Company. The lack of motivation of this utility for generating electricity from renewable energy sources has prevented the development of power generation in a more environmentally friendly manner domestically. The general public has no possibility to choose renewable energy sources for generating their consumed electricity. Through government legislation, the electricity market should be liberalized in order to allow enterprises to freely generate, purchase, and sell electricity on the market on the one hand, and to provide the general public with the opportunity to make a free choice of their electricity supplier on the other. Accordingly, environmentally friendly enterprises would be free to invest in power generation from renewable energy sources. Customers could also actively influence energy policy through their purchasing behavior.

\subsection{Public funds for demonstration projects}

For countries such as Taiwan where the development of wind energy is in the initial phases, demonstration plants at various sites could help provide project experience and educational opportunities in order to display various benefits of wind energy to citizens. The experience in India began with a small state-run demonstration plant in Mullaikadu. Later a wind farm with great installation capacity followed in Kayathar (Thothathri, 1999). This step-by-step approach is currently being used in many countries to promote power generation from various renewable energy sources.

\subsection{Financial incentives}

Financial incentives, such as special loans, favorable interest rates, etc., would be helpful to lighten the load of investment. The experience in Germany indicates that wind turbine owners have had access to low-interest loans. This is a complementary measure to attract investment.

\subsection{Raising awareness}

The scenario analysis developed by the Global Scenario Group has concluded that, in principle, a transition to sustainability appears to be technically feasible. A significant precondition is the emergence of sufficient political will for establishing a comprehensive set of policy reforms for a sustainability transition (National Research Council, 1999). Governmental agencies and the general public need to be informed about the ecological risks and the benefits of replacing fossil fuels and nuclear energy by renewable energy sources. Non-governmental environmental organizations have successfully informed the general public via the media about the necessity of labeling provisions for genetically modified foods in the past, and have urged the government to propose regulatory measures in Taiwan. These organizations could play a significant role in pressuring governmental agencies to actively enact legislation providing a favorable framework for the penetration of renewable energy sources in the market, while providing up-to-date information to citizens about renewable energy. These organizations could actively contact utilities, businesses, land owners, and farmers' associations to propose projects for the installation of wind turbines. They could also promote the cooperation between domestic and foreign manufacturer communities for localized wind turbine production.

\subsection{Local community wind turbines}

One application of wind energy which is gaining support is that of local community wind turbines. This usually involves a group of people from a local community buying a wind turbine or a group of wind turbines. The local community benefits from the sale of the electricity produced, or makes use of it for its own purposes locally. Over $50 \%$ of the wind turbines in Denmark are owned and operated in this way. There is an active Danish Windmill Owners' Association which provides support for people so involved. Such wind energy cooperatives are also active in the Netherlands and Germany (Boyle, 1996). Establishing such an organization would be helpful to provide support for local citizens to install wind turbines in Taiwan with consultative aid from environmental NGOs.

\subsection{Combination with energy savings and other renewable energy sources}

The predicted increase in primary energy consumption by $90 \%$ from 1997 to 2020 in Taiwan may impose great stress on a transition toward sustainable energy utilization. Far-reaching energy savings through changes in industrial structure and improvement of energy efficiency in all sectors are imperative in addition to the exploitation of renewable energy sources. Providing an energy 
advice service is a significant way to help households, businesses, and other organizations cut the energy they use for cooling, lighting, and appliances. On the other hand, it is necessary to exploit other renewable energy sources according to locally differential potentials. Wind energy in coastal areas is much greater than that in inland areas. Rural areas have a much greater biomasssupply potential than cities do. The combination of various renewable energy sources can provide complementary and more-sufficient power supplies, and consequently enhance the capability of electricity supply. Hybridization for wind, solar, biomass, and small hydro sources could provide ideal combinations, particularly for areas with small and decentralized wind potential, as illustrated in Fig. 12. Non-regulatable energy sources such as solar and wind energy can be combined with those that can be regulated-hydropower and biomass power plants - and matched with power demand. For areas with small and decentralized wind potential in Taiwan, hybrid systems with renewable sources are a feasible solution. The experience in inner Mongolia indicates that the linkage among wind turbines and photovoltaics are ideal applications for areas with small wind potential.

\subsection{International cooperation}

Paragraph (c), Article 10 of the Kyoto Protocol requires that all Parties cooperate in the promotion of effective modalities for the development, application, and diffusion of environmentally sound technologies, and practices pertinent to climate change including the formulation of policies and programs for the effective transfer of environmentally sound technologies. Countries like Taiwan can propose projects jointly with governmental development organizations of other countries or international development banks under the consideration of pursuing the global common interest of climate protection. The "Joint Implementation" mechanism which was introduced by the Kyoto Protocol aims to combat the formation of greenhouse gases wherever the greatest success can be achieved with the lowest possible financial investment. The successful stories of installing numerous wind turbines in Costa Rica, a system implemented under this framework with the US and Danish governments, imply that this mechanism provides possibilities to conduct bilateral or international state and private cooperation.

\subsection{Careful project planning and citizen participation}

It is crucially important for project planners to carefully plan the implementation of wind turbines without creating objections from people in the surrounding area, while at the same time taking transparency and citizen participation into account during the planning of wind power generation. Wide citizen participation in the region is important for the acceptance of wind energy. Citizens should be informed at an early date about the planned project. This is particularly important for Taiwan's special social conditions which have seen the iterative occurrence of demonstrations against the building of incinerators and landfills. Wind power is regarded as a sustainable energy generation pattern. Incinerations and landfills are generally deemed to have more ecological impacts. However, the building of these installations will cause concern from citizens about their potential impacts on local life support resources in the same way. Currently, wind energy is unfamiliar to citizens in Taiwan during this initial stage. Education through dialogue and publicity is particularly important in order to alleviate local citizens' concerns.

\section{Conclusions}

Mitigating global climate change by a transition toward sustainable energy use patterns represents a typical example explaining that growth should occur only within the carrying capacity of natural systems to assimilate those impacts in order to ensure the health of the human life support system. The developing world is entitled to expect better living standards in terms of goods and

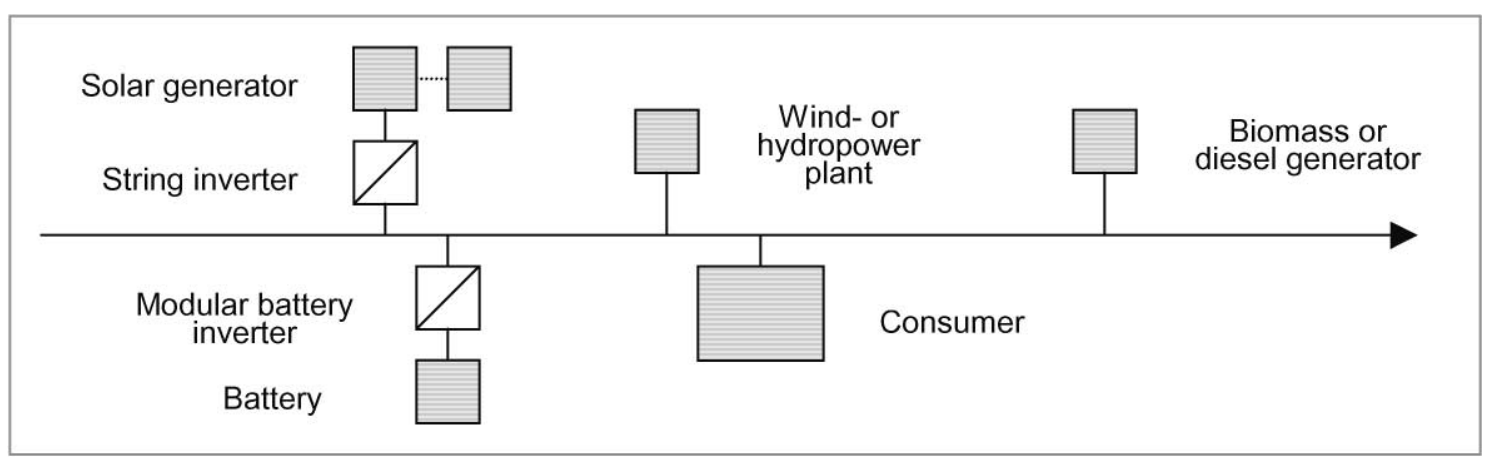

Fig. 12. Hybridization for wind, solar, biomass, and small hydro sources. 
services, but unless the global community encourages sustainable energy paths, global environmental problems will worsen. Wind energy is a sufficiently mature, costeffective, and widely applicable technology which can substantially contribute to mitigating global warming.

This study has reached the following conclusions:

- The current energy structure in Taiwan with a 98.8\% share by fossil fuels and nuclear energy and the continued trend of their dominant role in the future energy portfolio is not sustainable.

- Wind energy possesses a technical potential of about $4000 \mathrm{MW}$ in Taiwan. This would be capable of generating some $10 \mathrm{TWh}$ of electricity annually, covering about $3.3 \%$ of the entire electricity demand by 2020 in Taiwan.

- Replacing partial coal-based power generation by the full exploitation of wind energy would result in a reduction of 9.8 million tons of $\mathrm{CO}_{2}$ annually in Taiwan.

- The cost of wind power generation is currently competitive with that of fuel oil and natural gas in Taiwan. Taking into account the external costs of other fuel sources and system benefits of wind, wind's competitive position is strengthened.

- Wind energy simultaneously possesses economic, ecological, and social benefits, and would contribute to establishing an autonomous and disaster-resilient power supply system in Taiwan, an area subject to such phenomena as earthquakes and typhoons.

- Considering that the contribution of wind energy for covering total energy consumption appears limited, complementary measures such as energy conservation and exploitation of other renewable energy sources are required.

- Establishing the political impetus and a framework is the most important task for promoting renewable energy in Taiwan. The right mixture of raising awareness, incentives, and regulations is crucial for achieving market development of wind energy. Priority tasks include establishing a legislative priority for renewable energy, setting premium prices for power from wind turbines, providing direct support of investment costs, raising awareness, etc.

Considerations of the energy structure should be transformed from the traditional support of economic growth to the simultaneous consideration of human and ecological health, social welfare, and economic development. Electricity generation from wind power provides us with a new model of thinking: sustainable energy use patterns are achievable by simultaneously considering ecological, economic, and social imperatives. We are hopeful that the assessments in this study can help to lead a sustainable society to regard environmental and economic benefits as necessary and not controversial interests.

\section{References}

Boyle, G. (Ed.), 1996. Renewable Energy-Power for a Sustainable Future. Oxford University Press, Oxford.

Chang, W.P., Chan, C.-C., Wang, J.-D., 1997. ${ }^{60}$ Co contamination in recycled steel resulting in elevated civilian radiation doses, causes and challenges. Health Physics 73(3), 465-472.

DWTMA (Danish Wind Turbine Manufacturers Association), 2000. 21 Frequently Asked questions about Wind Energy. DWTMA Website: http://www.windpower.dk/faqs.htm.

ECDGE (European Commission's Directorate General for Energy), 1998. Wind Energy - The Facts. AGORES (A Global Overview of Renewable Energy Sources), website: http://www.agores.org/publications/Wind-Energy.htm.

ECROC (Energy Commission of the Republic of China), 1998. White Paper of Energy Policy of the Republic of China. Taipei, Taiwan.

ECROC (Energy Commission of the Republic of China), 1999. Final Report of Plan for Research and Exploitation of New Energy and Clean Energy. Taipei, Taiwan.

ECROC (Energy Commission of the Republic of China), 2000. The Analysis of Generation Costs and Amortisation of Renewable Energy Sources in Taiwan. Taipei, Taiwan.

EPA (Environmental Protection Administration) of the ROC (Republic of China), 1999. National Communication of the Republic of China. Taipei, Taiwan.

European Wind Energy Association, 2000. Wind Force 10-A Blueprint to Achieve $10 \%$ of the World's Electricity from Wind Power by 2020 .

Glaser, N., 2000. Pinning its hopes on renewables. New Energy (3), 26-27.

GWEA (German Wind Energy Association), 1998. 25 Fakten zur Windkraftnutzung in Deutschland (25 facts to the use of wind power in Germany). GWEA Website: http://www.wind-energie.de/ info/25fakten.pdf.

Hinsch, C., 1999. It's up to Brussels to prioritize defense of the independent producers. New Energy (4), 10-12.

IEA (International Energy Agency), 1999. Key World Energy Statistics. IEA Website: http://www.iea.org/stats/files/keystats/key99.pdf.

IPCC, 1996. Technologies, Policies and Measures for Mitigating Climate Change. IPCC Website: http://www.ipcc.ch/pub/ IPCCTP.I(E).pdf.

Kaltschmitt, M., Wiese, A., 1994. Technische energiepotentiale, substituerbare End- und Primärenergieäquivalente und Kosten ernerbarer Energieträger in Deutschland (Technical energy potential, replaceable end and primary energy equivalents and costs of renewable energy sources in Germany). Zeitschrift für Energiewirtschaft, 41-64.

Kirkby, J., O'keefe, P., Timberlake, L. (Ed.), 1995. The Earthscan Reader in Sustainable Development. Earthscan Publications, London.

Lee, M.Y., 2000. Building of the fourth nuclear power plant does not just depend on safety consideration. United Daily News, Taiwan, October 13, 2000.

Loske, R., 1996. Klimapolitik (Climate policy). Metropolis Verlag, Marburg, Germany.

Musiol, F., 1999. 75\% from sun, wind and biomass. Windblatt (3), 2.

National Research Council, 1999. Our Common Journey. National Academy Press, Washington, DC.

New Energy, 1998, No. 1, pp. 7.

New Energy, 2000, No. 4, pp. 44.

Pearce, D., 1993. Measuring Sustainable Development. Earthscan Publications, London.

Taiwan Power Company, 1999. Cost analyses of power generation in Taiwan. Working Paper of the Taiwan Power Company. Taipei, Taiwan.

Thothathri, R., 1999. The wind brought jobs and prosperity. New Energy (4), 28-30. 
UNCSD (UN Commission on Sustainable Development), 2000. Agenda 21. UNCSD Website: http://www.un.org/esa/sustdev/ agenda21text.htm.

van Wijk, A.J.M., Coelingh, J.P., 1993. Wind Potential in the OECD Countries. University of Utrecht, Utrecht, Netherlands.

Wang, J.-D., 2000. The risks of nuclear energy and the substitution alternatives. The Taiwan Law Review (67), 72-83.

WECD, 1987. Our Common Future. Oxford University Press, Oxford.
Weyant, J., Yanigisawa, Y., 1998. Energy and industry. In: Rayner, S., Malone, E.L. (Eds.), Human Choice and Climate Change. Vol 2: Resources and Technology. Battelle Press, Columbus, $\mathrm{OH}$, pp. 203-289.

Young, R. J., 1999. The Inventory of the Energyrelated Greenhouse Gas Emissions in Taiwan. Available: http://www.erl.itri.org.tw/ energy_ policy/EC/FY88/new08.htm. 